\title{
The effects of maternal depression on mothers' perceptions of the emotional and behavioural problems of their internationally adopted children
}

Krista Liskola ( $\square$ krista.liskola@hus.fi )

Helsingin Yliopisto

Hanna Raaska

Helsinki University Central Hospital: Helsingin seudun yliopistollinen keskussairaala

Helena Lapinleimu

Turku University Hospital: TYKS Turu yliopistollinen keskussairaala

Jari Lipsanen

University of Helsinki: Helsingin Yliopisto

Jari Sinkkonen

University of Turku: Turun Yliopisto

Marko Elovainio

University of Helsinki: Helsingin Yliopisto

Research article

Keywords: depression-distortion hypothesis, adoption, CBCL, GHQ

Posted Date: March 4th, 2021

DOl: https://doi.org/10.21203/rs.3.rs-271280/v1

License: (9) (i) This work is licensed under a Creative Commons Attribution 4.0 International License.

Read Full License 


\section{Abstract}

Background: Even though child psychopathology assessment guidelines emphasise comprehensive multi-method, multimodal, and multi-informant methodologies (Pelham, Fabiano, \& Massetti, 2005), maternal report symptom-rating scales often serve as the predominant source of information. Research has shown that parental mood symptomatology affects their reports of their offspring's psychopathology. For example, the depression-distortion hypothesis suggests that maternal depression promotes a negative bias in mothers' perceptions of their children's behavioural and emotional problems (Gartstein, Bridgett, Dishion, \& Kaufman, 2009). We investigated this difference in perception between adoptive mothers and their internationally adopted children. Most previous studies have suffered from the potential bias caused by the fact that parents and children share genetic risks. Our study design allows the elimination of passive gene-environment correlation, which is a phenomenon that occurs when there is a shared genetic background between a rearing parent and a child (Harold et al., 2011; Jaffee \& Price, 2007; Price \& Jaffee, 2008).

Methods: Data were derived from the Finnish Adoption (FinAdo) survey study (a subsample of adopted children aged between 9 and 12 years; $N=222$ ). The Child Behavior Checklist (CBCL) (Achenbach \& Ruffle, 2000) was used to assess the emotional and behavioural problems and competences of the adopted children. The CBCL was completed by the adoptive mothers and the adopted children. Maternal depressive symptoms were measured using the short version of the General Health Questionnaire (Goldberg \& Hillier, 1979).

Results: On average, mothers reported fewer total $\mathrm{CBCL}$ symptoms in their children than the children themselves ( 0.25 vs $0.38, p$-value $<0.01$ for difference). Mothers' depressive symptoms moderated the discrepancy in reporting internalizing symptoms ( $\beta=-0.14$ and $p$-value 0.01 for interaction), the total symptoms scores ( $\beta=-0.22$ and $p$-value $<0.001$ for interaction), and externalizing symptoms in girls in the CBCL.

Limitations: The major limitation of our study was its cross-sectional design and the fact that we only collected data in the form of questionnaires.

Conclusions: The results of our research support the depression-distortion hypothesis concerning the association between maternal depressive symptoms and child internalizing symptoms and externalizing symptoms in girls in a sample without genetic bias.

\section{Introduction}

In the assessment of emotional and behavioural psychiatric symptoms in children, the procedure of collecting and combining information from multiple sources (e.g. mother, father, therapist, teacher, foster parent) has become the standard of practice. However, research has consistently shown that the agreement between ratings of child behaviour by different informants is only low to moderate (Muller, Romer, \& Achtergarde, 2014), and considerable discrepancies have also been observed between parent 
and adolescent reports of adolescent behaviour (De Los Reyes \& Kazdin, 2005). Furthermore, it has been argued that the nature of discrepancies differs by type of behaviour (Ordway, 2011).

Some possible explanations have been given for this discrepancy. The depression-distortion hypothesis suggests that maternal depression promotes a negative bias in mothers' perceptions of their children's behavioural and emotional problems (J. Richters \& Pellegrini, 1989; J. E. Richters, 1992), with recent evidence indicating that this effect may be greater in questionnaires than in clinical interviews (Maoz et al., 2014). The Attribution Bias Context (ABC) model suggests that reporting discrepancies may result from discordant perspectives between informants (De Los Reyes \& Kazdin, 2005). Supporting the ABC model and depression-distortion hypothesis, previous research has demonstrated that parents' depression and anxiety are associated with over-reporting children's problem behaviours (De Los Reyes \& Kazdin, 2005; Gartstein et al., 2009; Hennigan, O'Keefe, Noether, Rinehart, \& Russell, 2006; Treutler \& Epkins, 2003). However, some research shows that when other variables, such as family functioning, are controlled, the impact of mood on ratings is non-significant or small (De Los Reyes et al., 2011; van der Toorn et al., 2010).

It has been argued that children of psychiatrically ill mothers show more symptomatic behaviour than do the children of healthy mothers (Boyle \& Pickles, 1997; Pilowsky et al., 2006), at least partly due to shared genetic background. Therefore, maternal psychopathology appears to be related to actual child psychopathology via genetic transmission, social learning processes, lack of maternal sensitivity, insecure attachment patterns, or inadequate or inconsistent parenting behaviour. Higher maternal ratings may thereby also reflect a truly higher level of mental health symptoms in their children. This alternative assumption has been called the accuracy model (Muller, Achtergarde, \& Furniss, 2011). Although the combinatory model suggesting that maternal ratings of child psychiatric symptoms might be influenced simultaneously by maternal pathologic distortions and by a truly increased level of child psychiatric symptoms may be reasonable, the evaluation of the relative effects of the two are difficult to detect when parents and children share genetic risks.

In this study, we investigated the influence of maternal psychopathology, more precisely depressive symptoms, on their rating of the emotional and behavioural problems of their internationally adopted children. We tested the effect of maternal depressive symptoms on the difference between maternal and child ratings. Paternal ratings were excluded, as the number of fathers who completed the questionnaires was low. Whereas most research on cross-informant agreement or discrepancy has focused on biological offspring, in our sample, these mother-child couples were genetically unrelated. We hypothesised that a discrepancy would also be observed between adoptive mothers and internationally adopted children.

\section{Methods}

\section{Participants}

This study is part of the ongoing FINnish ADOption (FinAdo) study. The target population of the study consists of all children internationally adopted through three legalised adoption organizations in Finland 
between 1985 and 2007. Data were gathered with questionnaires exploring information about the child, the adoptive family, and the parents themselves. The questionnaires were completed separately by the parents and their adoptees over 9 years of age. The study sample $(N=222)$ consisted of 124 female respondents $(55.86 \%)$ and 98 male respondents (44.14\%). The characteristics of the sample are shown in Table 1. The study was approved by the Ethics Committee of the Hospital District of Southwest Finland, and written and informed consent was obtained from the parents and the children themselves.

\section{Measures}

\section{Child-related background factors}

A specific questionnaire developed for the FinAdo study was used to gain knowledge about the characteristics of the children before and after adoption. The child-related variables included the children's gender, age at the time of adoption and at the time of responding to the questionnaire, continent of birth, the type and number of pre-adoption placements, and health history.

\section{Parental depressivesymptoms}

The General Health Questionnaire (GHQ) is a self-administered screening questionnaire designed for use in consulting settings to detect individuals with a diagnosable psychiatric disorder (Goldberg \& Hillier, 1979). The 12-item General Health Questionnaire (GHQ-12) is the most extensively used screening instrument for common mental disorders, in addition to being a more general measure of psychiatric wellbeing. Various versions of the GHQ-12 have been reported as useful for determining the presence of depression, and shorter (five-item) versions have shown good predictive validity (Aalto, Elovainio, Kivimaki, Uutela, \& Pirkola, 2012). In this study, we used a five-item questionnaire that enquired whether the parent had recently been able to enjoy his/her daily duties, been thinking of himself/herself as a worthless person, felt unhappy and depressed, lost his/her self-confidence, or felt quite happy. The questions were answered on a 4-point scale: $1=$ more than usual, $2=$ as much as usual, $3=$ less than usual, and $4=$ much less than usual. The first and last items were reverse coded, and all items were summed.

\section{The adopted children's emotional and behavioural problems}

The Child Behavior Checklist, a component of the Achenbach System of Empirically Based Assessment developed by Thomas M. Achenbach (Achenbach, 1991; Achenbach \& Ruffle, 2000) is a 118-question behavioural checklist that is completed by the child's parent or caretaker. It is an instrument designed to obtain data on children's behavioural/emotional problems and competencies, and it is widely used in clinical and research settings because of its demonstrated reliability and validity, ease of administration, and applicability to clinical and nonclinical groups (Dutra, Campbell, \& Westen, 2004). In our study, we chose to use the CBCL to measure behavioural problems because of its status as a well-known and often used method in adoption research and its good psychometric reliability (Hawk \& McCall, 2010; Juffer \& van ljzendoorn, 2005; Verhulst, Versluis-den Bieman, van der Ende, Berden, \& Sanders-Woudstra, 1990). 
The CBCL provides a total score for behavioural characteristics and separates scores for internalizing and externalizing behavioural symptoms. Internalizing behavioural symptoms reflects problems mainly within the self, such as anxiety, depression, somatic complaints without medical cause, and withdrawal from social contacts (Achenbach, 1991; Achenbach \& Ruffle, 2000). Externalizing behavioural signs include conflict with others and rule-breaking or aggressive behaviour (Achenbach, 1991; Achenbach \& Ruffle, 2000).

A high level of association between the CBCL and diagnoses derived via structured interviews has been documented (Chorpita et al., 2010). For example, studies have found associations between depressive disorders and the depression/anxiety, withdrawn, and somatic complaints subscales as well as with the broadband internalizing scale (Weinstein, Noam, Grimes, Stone, \& Schwab-Stone, 1990). Similarly, anxiety disorders have been significantly associated with elevated scores on the depression/anxiety subscale (Weinstein et al., 1990). In addition, these studies have found significant associations between conduct disorder and aggressive behaviour, delinquent behaviour, and the broadband externalizing subscales of the CBCL (Biederman et al., 1993; Biederman et al., 1995; Biederman, Faraone, Mick, Moore, \& Lelon, 1996; Edelbrock \& Costello, 1988).

We used the 113-question CBCL with participants aged 6 to 18 years (Hawk \& McCall, 2010). Each item was rated as (0) not true, (1) somewhat or sometimes true, and (2) very true or often true. The higher the child's scores in the $\mathrm{CBCL}$, the more behavioural problems the child has.

\section{Statistical analyses}

The associations between maternal depression and the CBCL were analysed using linear regression models with child CBCL reports as outcomes and maternal $C B C L$ reports as predictors. The interaction term between mothers' depressive symptoms and their CBCL reports was added into the models to test the significance of the difference between depressive and non-depressive mothers reporting discrepancy. All analyses were performed using $R$ analytics (v. 3.6.1).

\section{Results}

The mean level of depressive symptoms in mothers was $1.89(S D=0.51)$. The mean score of externalizing symptoms was $0.28(S D=0.32)$ for mothers and $0.38(S D=0.30)$ for children. For internalizing symptoms, the mean scores were $0.19(S D=0.20)$ for mothers and $0.33(S D=0.28)$ for children. The mean CBCL total score for mothers was $0.25(S D=0.24)$ and 0.38 for children $(S D=025)$. Mothers' depressive symptoms were not associated with their children's CBCL symptoms reported by themselves or by their children (Table 2).

There were significant interaction effects between mothers' depressive symptoms and mothers' reported internalizing symptoms; the $p$-values for the interaction ranged from 0.013 to 0.006 (Table 3 ). The greater the mothers' depressive symptoms, the less similar the mother- and child-reported symptoms were (Figure 1). A similar interaction effect was found between mothers' depressive symptoms and mothers' reported 
total CBCL score; the $p$-values ranged for the interaction effect from 0.010 to 0.001 (Table 4; Figure 2). There were also significant interaction effects between the mothers' depressive symptoms and mothers' reported externalizing symptoms; the $p$-values for the interaction ranged from 0.028 to 0.005 , but these effects were only evident in girls (third-level gender interactions: $p$-value range 0.025 to 0.011 ; Table 5). Again, the more depressive symptoms the mother had, the less similar the symptom reporting was between the mother and the child (Figure 3). All these models were adjusted for the child's age, age at arrival in Finland, and mother's SES.

\section{Discussion}

As in previous studies, our research revealed a discrepancy in reporting the emotional problems of children in this group of adopted children and their parents, who had no shared genetic background. Our study showed that maternal depressive symptoms were related with poor agreement on reports for the total $\mathrm{CBCL}$ score, internalizing symptoms, and for girls' externalizing symptoms, thus supporting the depression-distortion hypothesis.

It has been argued that the nature of discrepancies differs by type of behaviour. Some studies have found that there is higher agreement for externalizing problems, such as delinquent, aggressive, and antisocial behaviour, than internalizing problems, such as withdrawal, anxiety, and depression (Salbach-Andrae, Klinkowski, Lenz, \& Lehmkuhl, 2009; Stokes, Pogge, Wecksell, \& Zaccario, 2011; van der Meer, Dixon, \& Rose, 2008). This might be due to the fact that internalizing problems may be harder to observe (Karver, 2006), and externalizing problems may be more obvious, more consistent across situations, or more persistent (van der Meer et al., 2008). Moreover, some researchers have observed that parents tend to report more externalizing problems than adolescents (Berg-Nielsen, Vika, \& Dahl, 2003; Carlston \& Ogles, 2009); however, other studies have purported the converse (Barker, Bornstein, Putnick, Hendricks, \& Suwalsky, 2007; Sourander, Helstela, \& Helenius, 1999) or no difference (Huberty, Austin, Harezlak, Dunn, \& Ambrosius, 2000). Interestingly, some studies have found that parental depression is associated with higher agreement (Klaus, Mobilio, \& King, 2009; Reuterskiöld, Öst, \& Ollendick, 2008) and that parents with psychopathology may be more accurate reporters due to their awareness of and sensitivity to mental health symptoms (Hughes \& Gullone, 2010); Robinson et al.)

Furthermore, Hughes and Gullone (2010) stated that such discrepancies cannot indicate which informant is more accurate or whether informants are over- or under-reporting the children's behaviour. Rather, it could be argued that each informant provides unique information reflecting subjective, partial truths based on how and where they observe the behaviour (Berg-Nielsen et al., 2003; De Los Reyes et al., 2011).

The present study integrates and extends prior research on cross-informant discrepancy by using an adoption design to disentangle the contribution of genetic influences. A comparable study design was conducted by Tarren-Sweeney et al., who directed a study on interrater agreement between foster parents and teachers (Tarren-Sweeney et al., 2004). They concluded that teachers and foster parents demonstrated moderate to good agreement $(\mathrm{kappa}=0.70-0.79)$ in identifying clinically significant total 
problems and externalizing problems but poor agreement in identifying internalizing problems. However, their study did not address the potential discrepancy between the children and their foster parents. Because of this difference, the two studies are not fully comparable.

The finding that mothers with depressive symptoms and adopted girls report differently on externalizing symptoms is worth noticing. In the general population, females are considered at heightened risk for internalizing symptoms and males for externalizing symptoms. Watson et al. stated that in children of depressed parents, these normative gender differences may be even more evident, meaning that girls may be at even greater risk for internalizing problems and boys for externalizing problems. Hence, the question arises whether mothers with depressive symptoms are less tolerant and/or more sensitive to girls' externalizing symptoms.

Another interesting aspect of parent-child discrepancy is how much and what kind of information it can reflect about the relationship between parents and children, especially in adoptive families. For instance, the question of the relevance of attachment constructs arises. Attachment itself can be considered as related to the length of time the child has been living with the adoptive family.

\section{Strengths and limitations}

The results of our study must be considered in light of the study's strengths and limitations.

The major limitation was the cross-sectional design of our study. A longitudinal study would provide an opportunity to examine the stability and changes in maternal depressive symptoms and reporting of child behavioural problems by parents.

A considerable limitation of our study was the low number $(n=7)$ of mothers who had depressive symptoms. Additionally, the mothers did not suffer from clinical depression, having only mild symptoms. It should also be considered that some studies have shown that internationally adopted children demonstrate more internalizing symptoms than their non-adopted peers (Juffer \& van ljzendoorn, 2005).

Furthermore, adoptive parents have a lower threshold for referring their adolescents to treatment than biological parents, indicating that they might be more sensitive to potential problems and perhaps overestimate their occurrence (Askeland et al., 2017). Adoptive parents may also be more willing to seek help from a mental health professional for their troubled child because they are better educated or have greater economic resources than many non-adoptive parents or because they have previously interacted with social service providers in the adoption process. No prenatal information about the children or the life events they experienced before the moment they were adopted (except for the type and number of placements) was available.

\section{Conclusion}

The results of our research support the depression-distortion hypothesis in a study sample of genetically unrelated children and mothers, given the association of maternal depressive symptoms, the over- 
reporting of child internalizing symptoms, and girls' externalizing symptoms compared to the children themselves. It may be stated that clinicians and studies assessing children's psychopathology should take into account current parental mood. Furthermore, it would be of informative value to determine factors that influence agreement and discrepancies between informants. For instance, differences in parenting stress may be involved, especially when there is concurrent depression.

\section{Declarations}

\section{Acknowledgements}

M.E. was supported by the Academy of Finland (265977). K.L. was supported by the Ane and Signe Gyllenberg Foundation. The study was supported by the Foundation of Pediatric Research, Finland, the Ane and Signe Gyllenberg Foundation and EVO Grant from Turku University Hospital.

\section{Role of Funding Source}

Krista Liskola received a grant of $6000 €$ from the Ane and Signe Gyllenberg Foundation in 2019, which partly relates to the research reported in this article. The Ane and Sgne Gyllenberg had no role in either the gathering or the interpretation of these data presented in this article.

Marko Elovainio was supported by the Academy of Finland (265977).

The study was supported by the Foundation of Pediatric Research, Finland, the Ane and Signe Gyllenberg Foundation and EVO Grant from Turku University Hospital.

\section{Contributors}

Marko Elovainio and Helena Lapinleimu were responsible of the study concept and design. ME, $\mathrm{HL}$ and $\mathrm{HR}$ and contributed to the data acquisition. JL and ME performed the statistical analyses. KL provided the first version of the manuscript. ME, HL, HR and JS provided critical revision of the manuscript. All authors critically reviewed the content and approved the final version of this manuscript.

\section{Conflict of Interest Statement}

The authors declare that they have not had any financial support or other relationships that may have caused any conflict of interest.

\section{Ethics approval and consent to participate}

The study was approved by the Ethics Committee of the Hospital District of Southwest Finland, and written and informed consent was obtained from the parents and the children themselves.

\section{Consent for publication}

Not applicable. 
Availability of data and materials

The datasets during and/or analysed during the current study available from the corresponding author on reasonable request.

\section{References}

Aalto, A. M., Elovainio, M., Kivimaki, M., Uutela, A., \& Pirkola, S. (2012). The beck depression inventory and general health questionnaire as measures of depression in the general population: A validation study using the composite international diagnostic interview as the gold standard. Psychiatry Research, 197(12), 163-171. doi:10.1016/j.psychres.2011.09.008 [doi]

Achenbach, T. M. (1991). Manual for the child behavior checklist/4-18 and 1991 profile. burlington, vt: University of vermont, department of psychiatry.

Achenbach, T. M., \& Ruffle, T. M. (2000). The child behavior checklist and related forms for assessing behavioral/emotional problems and competencies. Pediatrics in Review, 21(8), 265-271. doi:10.1542/pir.21-8-265 [doi]

Askeland, K. G., Hysing, M., La Greca, A. M., Aaro, L. E., Tell, G. S., \& Sivertsen, B. (2017). Mental health in internationally adopted adolescents: A meta-analysis. Journal of the American Academy of Child and Adolescent Psychiatry, 56(3), 203-213.e1. doi:S0890-8567(16)31995-5 [pii]

Barker, E. T., Bornstein, M. H., Putnick, D. L., Hendricks, C., \& Suwalsky, J. T. D. (2007). Adolescent-mother agreement about adolescent problem behaviors: Direction and predictors of disagreement. Journal of Youth and Adolescence, 36(7), 950-962. doi:https://doi.org/10.1007/s10964-006-9164-0

Berg-Nielsen, T. S., Vika, A., \& Dahl, A. A. (2003). When adolescents disagree with their mothers: CBCL-YSR discrepancies related to maternal depression and adolescent self-esteem. Child: Care, Health and Development, 29(3), 207-213. doi:332 [pii]

Biederman, J., Faraone, S., Mick, E., Moore, P., \& Lelon, E. (1996). Child behavior checklist findings further support comorbidity between ADHD and major depression in a referred sample. Journal of the American Academy of Child and Adolescent Psychiatry, 35(6), 734-742. doi:S0890-8567(09)63908-3 [pii]

Biederman, J., Faraone, S. V., Doyle, A., Lehman, B. K., Kraus, I., Perrin, J., \& Tsuang, M. T. (1993). Convergence of the child behavior checklist with structured interview-based psychiatric diagnoses of ADHD children with and without comorbidity. Journal of Child Psychology and Psychiatry, and Allied Disciplines, 34(7), 1241-1251. doi:10.1111/j.1469-7610.1993.tb01785.x [doi]

Biederman, J., Milberger, S., Faraone, S. V., Kiely, K., Guite, J., Mick, E., . . Davis, S. G. (1995). Impact of adversity on functioning and comorbidity in children with attention-deficit hyperactivity disorder. Journal 
of the American Academy of Child and Adolescent Psychiatry, 34(11), 1495-1503. doi:S08908567(09)63969-1 [pii]

Boyle, M. H., \& Pickles, A. R. (1997). Influence of maternal depressive symptoms on ratings of childhood behaviour. Journal of Abnormal Child Psychology, (25), 399-412.

Carlston, D. L., \& Ogles, B. M. (2009). Age, gender, and ethnicity effects on parent-child discrepancy using identical item measures. Journal of Child and Family Studies, 18(2), 125-135.

doi:https://doi.org/10.1007/s10826-008-9213-2

Chorpita, B. F., Reise, S., Weisz, J. R., Grubbs, K., Becker, K. D., Krull, J. L., \& Research Network on Youth Mental Health. (2010). Evaluation of the brief problem checklist: Child and caregiver interviews to measure clinical progress. Journal of Consulting and Clinical Psychology, 78(4), 526-536.

doi:10.1037/a0019602 [doi]

De Los Reyes, A., \& Kazdin, A. E. (2005). Informant discrepancies in the assessment of childhood psychopathology: A critical review, theoretical framework, and recommendations for further study. Psychological Bulletin, 131(4), 483-509. doi:2005-08334-001 [pii]

De Los Reyes, A., Youngstrom, E. A., Swan, A. J., Youngstrom, J. K., Feeny, N. C., \& Findling, R. L. (2011). Informant discrepancies in clinical reports of youths and interviewers' impressions of the reliability of informants. Journal of Child and Adolescent Psychopharmacology, 21(5), 417-424.

doi:10.1089/cap.2011.0011 [doi]

Dutra, L., Campbell, L., \& Westen, D. (2004). Quantifying clinical judgment in the assessment of adolescent psychopathology: Reliability, validity, and factor structure of the child behavior checklist for clinician report. Journal of Clinical Psychology, 60(1), 65-85. doi:10.1002/jclp.10234 [doi]

Edelbrock, C., \& Costello, A. J. (1988). Convergence between statistically derived behavior problem syndromes and child psychiatric diagnoses. Journal of Abnormal Child Psychology, 16(2), 219-231. doi:10.1007/BF00913597 [doi]

Gartstein, M. A., Bridgett, D. J., Dishion, T. J., \& Kaufman, N. K. (2009). Depressed mood and maternal report of child behavior problems: Another look at the depression-distortion hypothesis. Journal of Applied Developmental Psychology, 30(2), 149-160. doi:10.1016/j.appdev.2008.12.001 [doi]

Goldberg, D. P., \& Hillier, V. F. (1979). A scaled version of the general health questionnaire. Psychological Medicine, 9(1), 139-145. doi:10.1017/s0033291700021644 [doi]

Harold, G. T., Rice, F., Hay, D. F., Boivin, J., van den Bree, M., \& Thapar, A. (2011). Familial transmission of depression and antisocial behavior symptoms: Disentangling the contribution of inherited and environmental factors and testing the mediating role of parenting. Psychological Medicine, 41(6), 11751185. doi:10.1017/S0033291710001753 [doi] 
Hawk, B., \& McCall, R. B. (2010). CBCL behavior problems of post-institutionalized international adoptees. Clinical Child and Family Psychology Review, 13(2), 199-211. doi:10.1007/s10567-010-0068-x [doi]

Hennigan, K. M., O'Keefe, M., Noether, C. D., Rinehart, D. J., \& Russell, L. A. (2006). Through a mother's eyes: Sources of bias when mothers with co-occurring disorders assess their children. The Journal of Behavioral Health Services \& Research, 33(1), 87-104. doi:10.1007/s11414-005-9005-z [doi]

Huberty, T. J., Austin, J. K., Harezlak, J., Dunn, D. W., \& Ambrosius, W. T. (2000). Informant agreement in behavior ratings for children with epilepsy. Epilepsy \& Behavior : E\&B, 1(6), 427-435. doi:S15255050(00)90119-7 [pii]

Hughes, E. K., \& Gullone, E. (2010). Discrepancies between adolescent, mother, and father reports of adolescent internalizing symptom levels and their association with parent symptoms. Journal of Clinical Psychology, 66(9), 978-995. doi:10.1002/jclp.20695 [doi]

Jaffee, S. R., \& Price, T. S. (2007). Gene-environment correlations: A review of the evidence and implications for prevention of mental illness. Molecular Psychiatry, 12(5), 432-442. doi:4001950 [pii]

Juffer, F., \& van ljzendoorn, M. H. (2005). Behavior problems and mental health referrals of international adoptees: A meta-analysis. Jama, 293(20), 2501-2515. doi:293/20/2501 [pii]

Klaus, N. M., Mobilio, A., \& King, C. A. (2009). Parent-adolescent agreement concerning adolescents' suicidal thoughts and behaviors. Journal of Clinical Child and Adolescent Psychology: The Official Journal for the Society of Clinical Child and Adolescent Psychology, American Psychological Association, Division 53, 38(2), 245-255. doi:10.1080/15374410802698412 [doi]

Maoz, H., Goldstein, T., Goldstein, B. I., Axelson, D. A., Fan, J., Hickey, M. B., . . Birmaher, B. (2014). The effects of parental mood on reports of their children's psychopathology. Journal of the American Academy of Child and Adolescent Psychiatry, 53(10), 1111-22.e5. doi:10.1016/j.jaac.2014.07.005 [doi]

Muller, J. M., Achtergarde, S., \& Furniss, T. (2011). The influence of maternal psychopathology on ratings of child psychiatric symptoms: An SEM analysis on cross-informant agreement. European Child \& Adolescent Psychiatry, 20(5), 241-252. doi:10.1007/s00787-011-0168-2 [doi]

Muller, J. M., Romer, G., \& Achtergarde, S. (2014). Correction of distortion in distressed mothers' ratings of their preschool-aged children's internalizing and externalizing scale score. Psychiatry Research, 215(1), 170-175. doi:10.1016/j.psychres.2013.10.035 [doi]

Ordway, M. R. (2011). Depressed mothers as informants on child behavior: Methodological issues. Research in Nursing \& Health, 34(6), 520-532. doi:10.1002/nur.20463 [doi]

Pelham, W. E.,Jr, Fabiano, G. A., \& Massetti, G. M. (2005). Evidence-based assessment of attention deficit hyperactivity disorder in children and adolescents. Journal of Clinical Child and Adolescent Psychology : 
The Official Journal for the Society of Clinical Child and Adolescent Psychology, American Psychological Association, Division 53, 34(3), 449-476. doi:10.1207/s15374424jccp3403_5 [doi]

Pilowsky, D. J., Wickramaratne, P. J., Rush, A. J., Hughes, C. W., Garber, J., Malloy, E., .. Weissman, M. M. (2006). Children of currently depressed mothers: A STAR*D ancillary study. The Journal of Clinical Psychiatry, 67(1), 126-136. doi:10.4088/jcp.v67n0119 [doi]

Price, T. S., \& Jaffee, S. R. (2008). Effects of the family environment: Gene-environment interaction and passive gene-environment correlation. Developmental Psychology, 44(2), 305-315. doi:10.1037/00121649.44.2.305 [doi]

Reuterskiöld, L., Öst, L., \& Ollendick, T. (2008). Exploring child and parent factors in the diagnostic agreement on the anxiety disorders interview schedule. Journal of Psychopathology and Behavioral Assessment, (30), 279-290. doi:https://doi.org/10.1007/s10862-008-9081-5

Richters, J., \& Pellegrini, D. (1989). Depressed mothers' judgment about their children: An examinatin of depression-distortion hypothesis. Cihld Development, (50), 1068-1075. doi:2805884

Richters, J. E. (1992). Depressed mothers as informants about their children: A critical review of the evidence for distortion. Psychological Bulletin, 112(3), 485-499. doi:10.1037/0033-2909.112.3.485 [doi]

Salbach-Andrae, H., Klinkowski, N., Lenz, K., \& Lehmkuhl, U. (2009). Agreement between youth-reported and parent-reported psychopathology in a referred sample. European Child \& Adolescent Psychiatry, 18(3), 136-143. doi:10.1007/s00787-008-0710-z [doi]

Sourander, A., Helstela, L., \& Helenius, H. (1999). Parent-adolescent agreement on emotional and behavioral problems. Social Psychiatry and Psychiatric Epidemiology, 34(12), 657-663. doi:10.1007/s001270050189 [doi]

Stokes, J., Pogge, D., Wecksell, B., \& Zaccario, M. (2011). Parent-child discrepancies in report of psychopathology: The contributions of response bias and parenting stress. Journal of Personality Assessment, 93(5), 527-536. doi:10.1080/00223891.2011.594131 [doi]

Treutler, C. M., \& Epkins, C. C. (2003). Are discrepancies among child, mother, and father reports on children's behavior related to parents' psychological symptoms and aspects of parent-child relationships? Journal of Abnormal Child Psychology, 31(1), 13-27. doi:10.1023/a:1021765114434 [doi]

van der Meer, M., Dixon, A., \& Rose, D. (2008). Parent and child agreement on reports of problem behaviour obtained from a screening questionnaire, the SDQ. European Child \& Adolescent Psychiatry, 17(8), 491-497. doi:10.1007/s00787-008-0691-y [doi]

van der Toorn, S. L., Huizink, A. C., Utens, E. M., Verhulst, F. C., Ormel, J., \& Ferdinand, R. F. (2010). Maternal depressive symptoms, and not anxiety symptoms, are associated with positive mother-child 
reporting discrepancies of internalizing problems in children: A report on the TRAILS study. European Child \& Adolescent Psychiatry, 19(4), 379-388. doi:10.1007/s00787-009-0062-3 [doi]

Verhulst, F. C., Versluis-den Bieman, H., van der Ende, J., Berden, G. F., \& Sanders-Woudstra, J. A. (1990). Problem behavior in international adoptees: III. diagnosis of child psychiatric disorders. Journal of the American Academy of Child and Adolescent Psychiatry, 29(3), 420-428. doi:S0890-8567(09)65150-9 [pii]

Weinstein, S. R., Noam, G. G., Grimes, K., Stone, K., \& Schwab-Stone, M. (1990). Convergence of DSM-III diagnoses and self-reported symptoms in child and adolescent inpatients. Journal of the American Academy of Child and Adolescent Psychiatry, 29(4), 627-634. doi:S0890-8567(09)64650-5 [pii]

\section{Tables}

Table 1 Characteristics of the sample

\begin{tabular}{|c|c|c|}
\hline Characteristics & Mean (SD) & N (\%) \\
\hline Total number of children & & 222 \\
\hline \multicolumn{3}{|l|}{ Gender } \\
\hline Boys & & $99(44.14)$ \\
\hline Girls & & $124(55.86)$ \\
\hline Age at arrival in Finland & $3.7(2.6)$ & \\
\hline Boys & $4.4(2.8)$ & \\
\hline Girls & $3.2(2.2)$ & \\
\hline Age at time of estimation & $14.0(0.9)$ & \\
\hline Boys & $14.1(0.9)$ & \\
\hline Girls & $13.9(0.9)$ & \\
\hline \multicolumn{3}{|l|}{ Continent of birth } \\
\hline Asia & & 47 (21.17) \\
\hline Europe & & $41(8.46)$ \\
\hline Africa & & $13(5.86)$ \\
\hline America & & $31(13.96)$ \\
\hline Not available & & $90(40.54)$ \\
\hline \multicolumn{3}{|c|}{ Type of placements before adoption } \\
\hline Orphanage & & $74(33.33)$ \\
\hline Foster home & & $19(8.56)$ \\
\hline Multiple placements & & $129(58.11)$ \\
\hline \multicolumn{3}{|l|}{ Mother's employment status } \\
\hline Managerial employee & & $88(39.6)$ \\
\hline Clerical worker & & $40(18.0)$ \\
\hline Worker & & $80(36.0)$ \\
\hline Other & & $14(6.3)$ \\
\hline Mother's age & $37.86(5.36)$ & \\
\hline
\end{tabular}


Table 2 Means, standard deviations, and correlations with confidence intervals

\begin{tabular}{|c|c|c|c|c|c|c|c|c|}
\hline Variable & $M$ & $S D$ & 1 & 2 & 3 & 4 & 5 & 6 \\
\hline $\begin{array}{l}\text { 1. Depression } \\
\text { (mother) }\end{array}$ & 1.89 & 0.51 & & & & & & \\
\hline $\begin{array}{l}\text { 2. CBCL Internal } \\
\text { (mother) }\end{array}$ & 0.19 & 0.20 & $\begin{array}{c}.12 \\
{[-.01, .25]}\end{array}$ & & & & & \\
\hline $\begin{array}{l}\text { 3. CBCL External } \\
\text { (mother) }\end{array}$ & 0.28 & 0.32 & $\begin{array}{c}.07 \\
{[-.06, .20]}\end{array}$ & $\begin{array}{c}.52 * * \\
{[.41, .61]}\end{array}$ & & & & \\
\hline $\begin{array}{l}\text { 4. CBCL Total } \\
\text { (mother) }\end{array}$ & 0.25 & 0.24 & $\begin{array}{c}.07 \\
{[-.06, .20]}\end{array}$ & $\begin{array}{c}.83^{* *} \\
{[.78, .87]}\end{array}$ & $\begin{array}{c}.83 * * \\
{[.78, .87]}\end{array}$ & & & \\
\hline $\begin{array}{l}\text { 5. CBCL Internal } \\
\text { (self) }\end{array}$ & 0.33 & 0.28 & $\begin{array}{l}-.02 \\
{[-.15, .11]}\end{array}$ & $\begin{array}{c}.35^{* *} \\
{[.23, .46]}\end{array}$ & $\begin{array}{c}.11 \\
{[-.02, .24]}\end{array}$ & $\begin{array}{c}.26^{* *} \\
{[.14, .38]}\end{array}$ & & \\
\hline $\begin{array}{l}\text { 6. CBCL External } \\
\text { (self) }\end{array}$ & 0.38 & 0.27 & $\begin{array}{l}-.07 \\
{[--20, .06]}\end{array}$ & $\begin{array}{c}.23 * * \\
{[.10, .35]}\end{array}$ & $\begin{array}{c}.50 * * \\
{[.40, .60]}\end{array}$ & $\begin{array}{c}.38^{* *} \\
{[.26, .49]}\end{array}$ & $\begin{array}{c}.56 * * \\
{[.46, .64]}\end{array}$ & \\
\hline $\begin{array}{l}\text { 7. CBCL Total } \\
\text { (self) }\end{array}$ & 0.38 & 0.25 & $\begin{array}{l}-.04 \\
{[-.17, .09]}\end{array}$ & $\begin{array}{c}.32 * * \\
{[.20, .43]}\end{array}$ & $\begin{array}{c}.26^{* *} \\
{[.14, .38]}\end{array}$ & $\begin{array}{c}.33 * * \\
{[.21, .44]}\end{array}$ & $\begin{array}{c}.92 * * \\
{[.89, .93]}\end{array}$ & $\begin{array}{c}.79 * * \\
{[.74, .84]}\end{array}$ \\
\hline
\end{tabular}

Note. $M$ and $S D$ are used to represent mean and standard deviation, respectively. Values in square brackets indicate the $95 \%$ confidence interval for each correlation. The confidence interval is a plausible range of population correlations that could have caused the sample correlation (Cumming, 2014). * indicates $p$ $<.05$. $* *$ indicates $p<.01$

Table 3 Interaction between mother-rated CBCL internalizing symptoms and maternal depression for child-rated CBCL internalizing symptoms. Figures are standardized regression coefficients (Beta) and 95\% confidence intervals (CI) and coefficients of determination ( $\mathrm{R} \rrbracket$ ). Adjusted for child's age, age at arrival to Finland and mother's SES.

\begin{tabular}{|c|c|c|c|c|c|c|c|c|c|}
\hline \multirow[b]{2}{*}{ Predictors } & \multicolumn{3}{|c|}{ CBCL Internal (child) } & \multicolumn{3}{|c|}{ CBCL External (child) } & \multicolumn{3}{|c|}{ CBCL Total (child) } \\
\hline & Beta & $95 \% C I$ & $p$ & Beta & $95 \% C I$ & $p$ & Beta & $95 \% C I$ & $p$ \\
\hline Depression (mother) & -0.02 & $\begin{array}{c}-0.15- \\
0.11\end{array}$ & 0.725 & -0.08 & $\begin{array}{c}-0.21- \\
0.06\end{array}$ & 0.280 & -0.06 & $\begin{array}{c}-0.19- \\
0.08\end{array}$ & 0.404 \\
\hline CBCL Internal (parent) & 0.36 & $\begin{array}{c}0.24- \\
0.48\end{array}$ & $<0.001$ & 0.27 & $\begin{array}{c}0.14- \\
0.40\end{array}$ & $<0.001$ & 0.34 & $\begin{array}{c}0.22- \\
0.47\end{array}$ & $<0.001$ \\
\hline $\begin{array}{l}\text { Depression (mother) x CBCL Internal } \\
\text { (parent) }\end{array}$ & -0.15 & $\begin{array}{l}-0.26- \\
-0.04\end{array}$ & 0.010 & -0.15 & $\begin{array}{c}-0.27- \\
-0.03\end{array}$ & 0.013 & -0.16 & $\begin{array}{l}-0.27- \\
-0.04\end{array}$ & 0.006 \\
\hline Observations & 222 & & & 222 & & & 222 & & \\
\hline $\mathrm{R}^{2} / \mathrm{R}^{2}$ adjusted & 0.210 & .176 & & 0.128 & .091 & & 0.178 & 0.143 & \\
\hline
\end{tabular}

Table 4 Interaction of total CBCL symptoms and maternal depression, adjusted for child's age, age at arrival to Finland and mother's SES. 


\begin{tabular}{|c|c|c|c|c|c|c|c|c|c|}
\hline \multirow[b]{2}{*}{ Predictors } & \multicolumn{3}{|c|}{ CBCL Internal (child) } & \multicolumn{3}{|c|}{ CBCL External (child) } & \multicolumn{3}{|c|}{ CBCL Total (child) } \\
\hline & Beta & $95 \% C I$ & $p$ & Beta & $95 \% C I$ & $p$ & Beta & $95 \% C I$ & $p$ \\
\hline Depression (mother) & -0.03 & $\begin{array}{c}-0.16- \\
0.10\end{array}$ & 0.703 & -0.10 & $\begin{array}{c}-0.23- \\
0.02\end{array}$ & 0.119 & -0.07 & $\begin{array}{c}-0.20- \\
0.06\end{array}$ & 0.303 \\
\hline CBCL Total (parent) & 0.27 & $\begin{array}{c}0.15- \\
0.40\end{array}$ & $<0.001$ & 0.38 & $\begin{array}{c}0.26- \\
0.50\end{array}$ & $<0.001$ & 0.33 & $\begin{array}{c}0.21- \\
0.45\end{array}$ & $<0.001$ \\
\hline $\begin{array}{l}\text { Depression (mother) x CBCL Total } \\
\text { (parent) }\end{array}$ & -0.20 & $\begin{array}{c}-0.34- \\
-0.06\end{array}$ & 0.005 & -0.18 & $\begin{array}{c}-0.31- \\
-0.04\end{array}$ & 0.010 & -0.23 & $\begin{array}{c}-0.36- \\
-0.09\end{array}$ & 0.001 \\
\hline Observations & 222 & & & 222 & & & 222 & & \\
\hline $\mathrm{R}^{2} / \mathrm{R}^{2}$ adjusted & 0.179 & .144 & & 0.213 & .180 & & 0.201 & .167 & \\
\hline
\end{tabular}

Figures are standardized regression coefficients (Beta) and 95\% confidence intervals (CI) and coefficients of determination (R])

Table 5 Interaction of CBCL externalizing symptoms and maternal depression, adjusted for child's age, age at arrival to Finland and mother's SE

Boys

\begin{tabular}{|c|c|c|c|c|c|c|c|c|c|}
\hline \multirow[b]{2}{*}{ Predictors } & \multicolumn{3}{|c|}{ CBCL Internal (child) } & \multicolumn{3}{|c|}{ CBCL External (child) } & \multicolumn{3}{|c|}{ CBCL Total (child) } \\
\hline & Beta & $95 \% C I$ & $p$ & Beta & $95 \% C I$ & $p$ & Beta & $95 \% C I$ & $p$ \\
\hline Depression (mother) & -0.11 & $\begin{array}{c}-0.33- \\
0.10\end{array}$ & 0.363 & -0.26 & $\begin{array}{c}-0.42- \\
-0.09\end{array}$ & 0.002 & -0.22 & $\begin{array}{l}-0.41- \\
-0.03\end{array}$ & 0.043 \\
\hline CBCL External (parent) & 0.40 & $\begin{array}{c}0.20- \\
0.60\end{array}$ & $<0.001$ & 0.72 & $\begin{array}{c}0.57- \\
0.87\end{array}$ & $<0.001$ & 0.53 & $\begin{array}{c}0.34- \\
0.71\end{array}$ & $<0.001$ \\
\hline $\begin{array}{l}\text { Depression (mother) x CBCL External } \\
\text { (parent) }\end{array}$ & -0.06 & $\begin{array}{c}-0.27- \\
0.16\end{array}$ & 0.614 & 0.05 & $\begin{array}{c}-0.12- \\
0.21\end{array}$ & 0.565 & -0.07 & $\begin{array}{c}-0.27- \\
0.13\end{array}$ & 0.486 \\
\hline Observations & 98 & & & 98 & & & 98 & & \\
\hline $\mathrm{R}^{2} / \mathrm{R}^{2}$ adjusted & 0.199 & .127 & & 0.539 & .498 & & 0.344 & 0.285 & \\
\hline
\end{tabular}

Girls

\begin{tabular}{|c|c|c|c|c|c|c|c|c|c|}
\hline \multirow[b]{2}{*}{ Predictors } & \multicolumn{3}{|c|}{ CBCL Internal (child) } & \multicolumn{3}{|c|}{ CBCL External (child) } & \multicolumn{3}{|c|}{ CBCL Total (child) } \\
\hline & Beta & $95 \% C I$ & $p$ & Beta & $95 \% C I$ & $p$ & Beta & $95 \% C I$ & $p$ \\
\hline Depression (mother) & -0.08 & $\begin{array}{c}-0.27- \\
0.11\end{array}$ & 0.187 & -0.12 & $\begin{array}{c}-0.29- \\
0.06\end{array}$ & 0.073 & -0.10 & $\begin{array}{c}-0.28- \\
0.08\end{array}$ & 0.076 \\
\hline CBCL External (parent) & 0.05 & $\begin{array}{c}-0.13- \\
0.23\end{array}$ & 0.498 & 0.28 & $\begin{array}{c}0.11- \\
0.45\end{array}$ & 0.001 & 0.13 & $\begin{array}{c}-0.04- \\
0.31\end{array}$ & 0.107 \\
\hline $\begin{array}{l}\text { Depression (mother) x CBCL External } \\
\text { (parent) }\end{array}$ & -0.28 & $\begin{array}{c}-0.52- \\
-0.03\end{array}$ & 0.028 & -0.28 & $\begin{array}{l}-0.51- \\
-0.05\end{array}$ & 0.017 & -0.34 & $\begin{array}{c}-0.58- \\
-0.11\end{array}$ & 0.005 \\
\hline Observations & 124 & & & 124 & & & 124 & & \\
\hline $\mathrm{R}^{2} / \mathrm{R}^{2}$ adjusted & 0.087 & .024 & & 0.188 & .131 & & 0.156 & .097 & \\
\hline
\end{tabular}




\section{Figures}

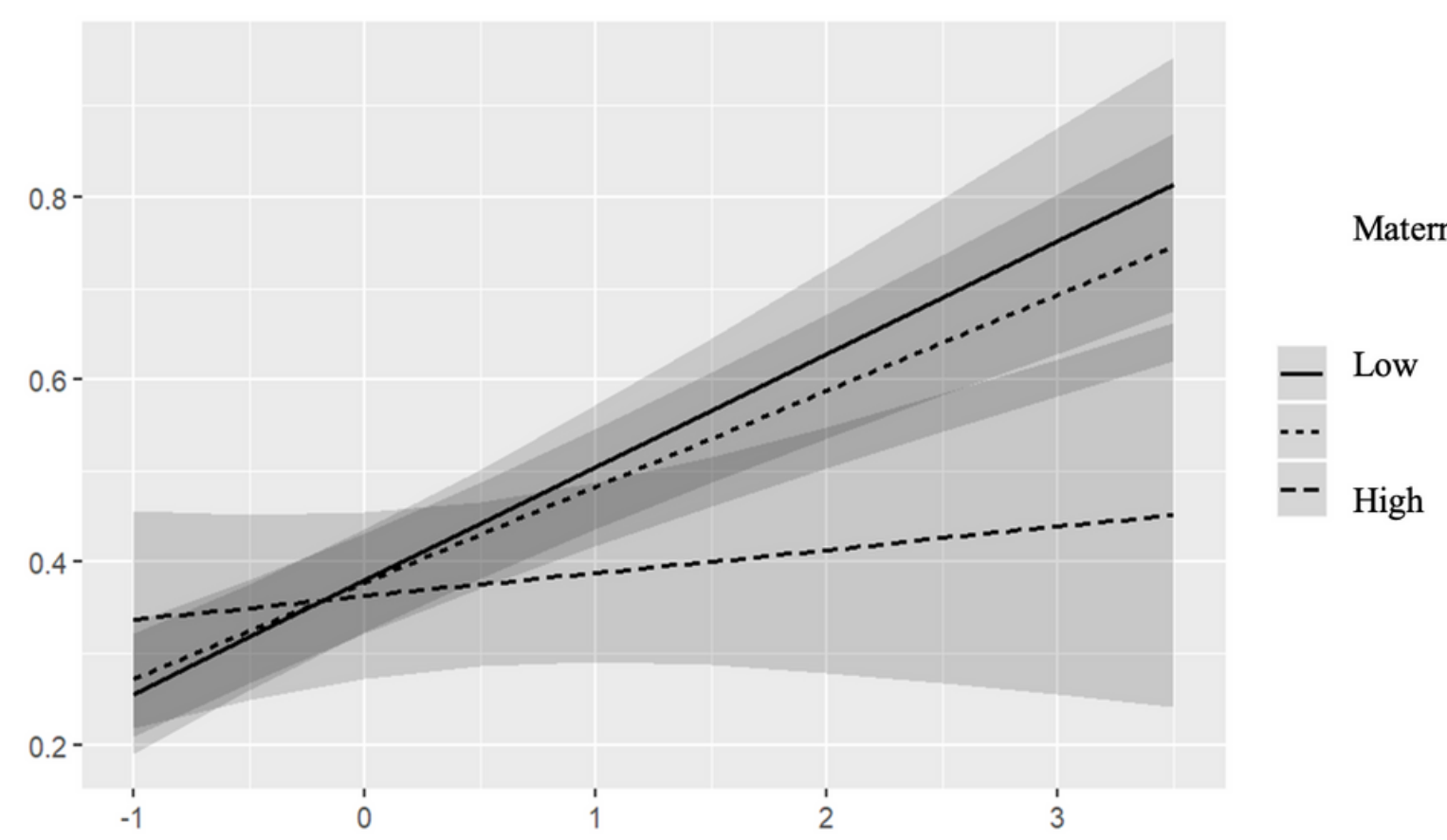

\section{Figure 1}

Interaction effect between mothers depressive symptoms (classified as high $=+1 \mathrm{SD}$, and Low $=-1 \mathrm{SD}$ ) and mother-rated internalizing symptoms for child-rated internalizing symptoms (testing modifying effect of mothers depressive symptoms in mother and child-rated similarity in internalizing symptoms). 


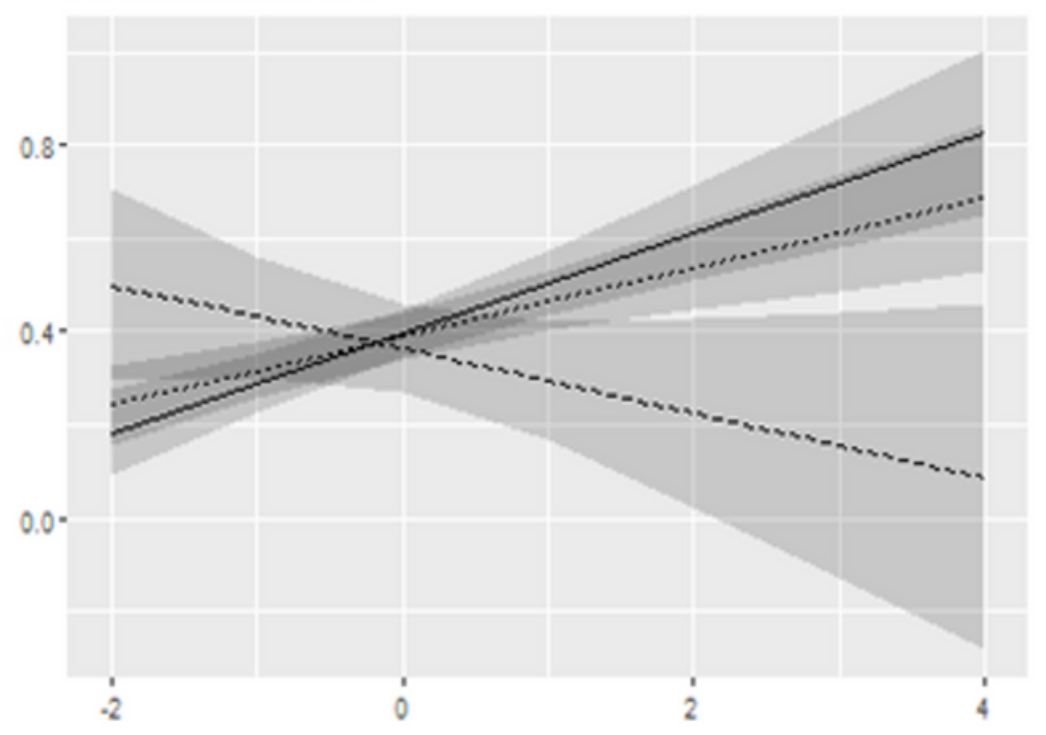

Maternal depressive symptoms

Low

High

\section{Figure 2}

Interaction effect between mothers depressive symptoms (classified as high $=+1 \mathrm{SD}$, and Low $=-1 \mathrm{SD}$ ) and mother-rated total CBCL symptoms for child-rated total CBCL symptoms (testing modifying effect of mothers depressive symptoms in mother and child-rated similarity in total CBCL symptoms).

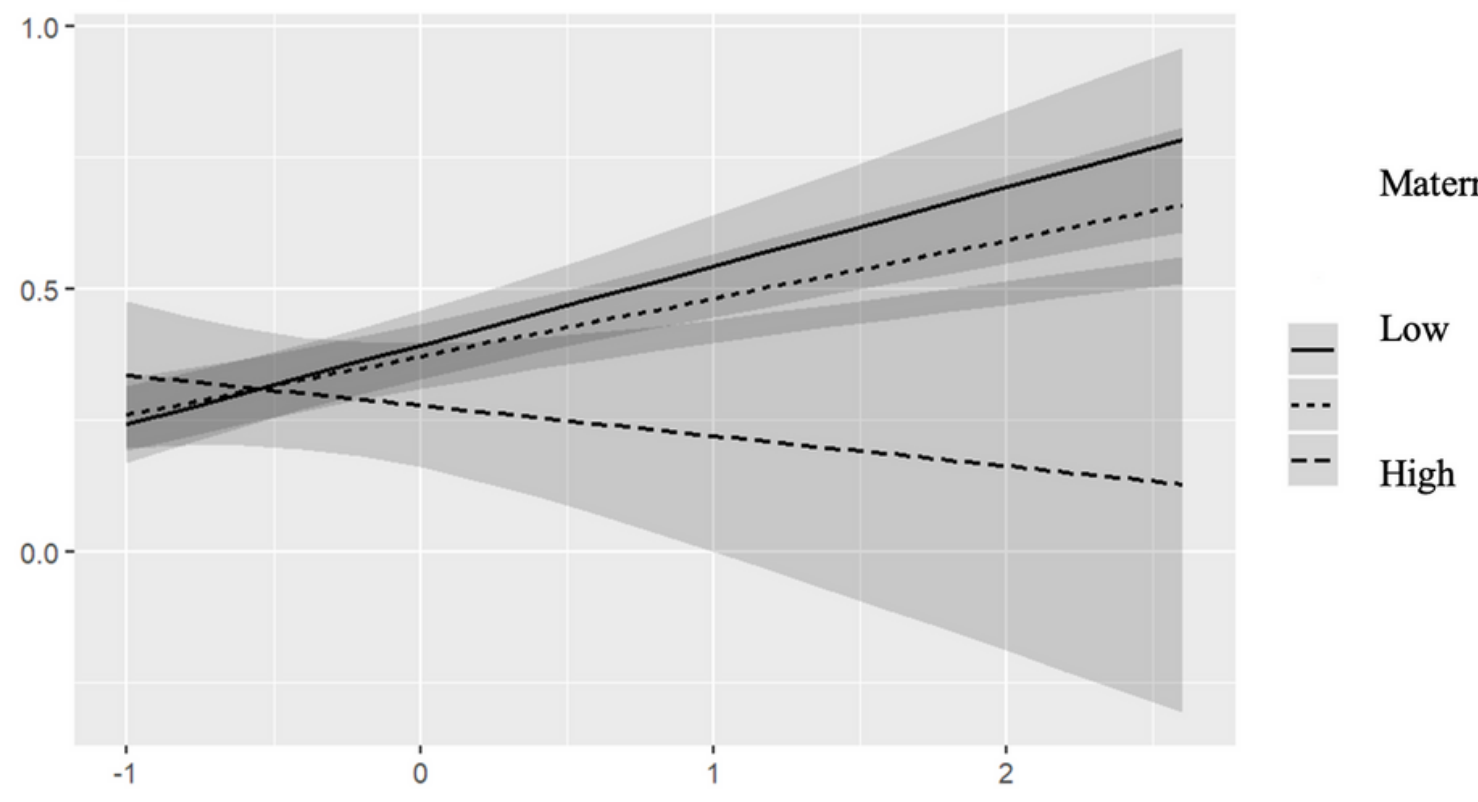

\section{Figure 3}

Interaction effect between mothers depressive symptoms (classified as high $=+1 \mathrm{SD}$, and Low $=-1 \mathrm{SD}$ ) and mother-rated externalizing symptoms for child-rated externalizing symptoms (testing modifying 
effect of mothers depressive symptoms in mother and child-rated similarity in externalizing symptoms). 